\title{
The Influence of Peer Education on The Change of Knowledge and Attitudes in The Prevention of HIV/AIDS in Fruit Vessel in Batu Ampar Port Area
}

\author{
Mira Agusthia ${ }^{1}$, Winda Ramadhana ${ }^{2}$ \\ ${ }^{1,2}$ Nursing, STIKes Awal Bros Batam, Indonesia \\ 1agusthiamira@gmail.com, ${ }^{2}$ windaramadhana@gmail.com
}

\section{Keyword:}

HIV/AIDS;

Peer Education;

Crewman.
ABSTRACT

Human Immunodeficiency Virus (HIV) is a virus that attacks the human immune system, especially all cells that have CD4 + markers on their surface such as macrophages and T lymphocytes, HIV infection can cause Acquired Immunodeficiency Syndrome (AIDS) which is characterized by gradual damage to immunity. AIDS affects immunity and even the autoimmunity. Kepulauan Riau health office notes Batam city is the highest case with 758 case HIV and 712 case AIDS. The result of mobile VCT service In BatuAmpar Health Quarantine at 2017 Showed from 2639 test of the high risk group (crewman, port warker, drivers ) 9 crewman infection HIV. The Purpose of This Studywas to determine the effect of giving peer education to change knowledge and attidues of crewman about prevention of HIV/AIDS in BatuAmpar International Cargo Port. This study was conducted on January 15, 2019. This study used a quasiexperimental method with the design of one group pretest-posttest design. The sample for this study used a purposive sampling method with a total sample of 20 respondents. The intervention that was carried out was the crew man which as the peer educator provided education about HIV/AIDS 3 times a week for 2 weeks in other crew man. Data were analyzed by paired T-tests (t-tests) which were previously tested for the Shapiro Wilk Normality Test. The results showed that there was an effect of peer education on changes in knowledge and attitudes in crew man in the prevention of HIV/AIDS in BatuAmpar port which was significant with a pvalue of $0,000(p<0.05)$. This study leads to the conclusion that there is an effect of peer education on changes in knowledge and attitudes in crew man in the prevention of HIV/AIDS. It is expected that the implementation of the peer education HIV/AIDS intervention will be increased at BatuAmpar port so that the crew man will know information about HIV/AIDS.

\section{A. INTRODUCTION}

Human Immunodeficiency Virus (HIV) is a pathogen that attacks the human immune system, especially all cells that have a CD4 + marker on its surface such as macrophages and $\mathrm{T}$ lymphocytes, HIV infection can cause Acquired Immunodeficiency Syndrome (AIDS) disease which is characterized by the gradually deterioration in the immune-inoperative immunity of $\mathrm{T}$ cells. AIDS affects immunity and even autoimmunity because of the central role of $\mathrm{T}$ - 
lymphocytes in immune reactions. The resulting immunodefesiensi makes the patient susceptible to opportunistic infections, cancer, and other abnormalities that Mark AIDS, Acquired Immunodeficiency Syndrome (AIDS) is an immunosuppressive condition (syndrome) closely related to various opurtunistic infections, secondary neoplasms, as well as certain neurologic manifestations due to HIV infection. (Tanto, Liwang, Hanifan, \& Pradipta, 2014)

The epidemic United Nations Programme on HIV and AIDS report shows that the total number of Human Immunodeficiency Virus (HIV) infections or HIV-infected people around the world in 2016 reaches 36.7 million increase by $0.54 \%$ in 2017 where the number of people infected by HIV reaches 36.9 million, of which 35.1 million is an adult and 1.8 million children less than 15 years old. Meanwhile, the number of deaths from AIDS in 20161 million people decreased by $0.06 \%$ in 2017940,000 of the population. The number of HIV infections in 2017 shows that East and South African countries are the highest HIV countries around the world where 19.6 people (53\%) Population suffers from HIV, and Asia and the Pacific 5.2 million (14\%) Third highest position thereafter (UNAIDS, 2017).

The number of HIV cases in Indonesia in 2016 reached 41,250 people increased by $17.9 \%$ in 2017 (48,300 people). The case of 2016 AIDS in 10,146 decreased by $8.53 \%$ in 2017 (9280 people). The highest HIV infection area in 2017 is in East Java $(8,204)$, while the Riau Islands province ranks 11 out of 33 provinces with a total of 1,105 HIV cases and 208 AIDS cases. (Ministry of Health Republic Indonesia, 2018)

Based on data from Riau Islands Provincial Health office until December 2017, the city of Batam ranks first with the number of 758 cases of HIV and 712 AIDS cases. The cumulative percentage of HIV cases in 2017 is based on age groups including the highest percentage of age in the age group of 25-49 years (69.3\%), followed by the group Age 20-24 (17.1\%), and age group $\geqslant 50$ years $(7.3 \%)$. While the highest AIDS percentage in the age group was 30-39 years (35.2\%), followed by the age group of $20-29$ years $(29.5 \%)$ and age group $40-49$ years $(17.7 \%)$. Cumulative percentage of HIV cases based on gender, the highest percentage in males $63.6 \%$ and females 36.4\%. (Dinas Kesehatan Provinsi Riau, 2015)

Various efforts have been done by the world Organization and the Indonesian Government in the problem of spreading HIV/AIDS, the handling is preventive, promotive, curative and rehabilitative. The government has set several policies and programmes against the spread of HIV/AIDS. The Government has made serious commitments to improve surveillance such as improving treatment, support, and treatment. Community empowerment efforts in the prevention of HIV/AIDS conducted by the government through counseling and health education (Hadati, Linda, \& Masudin, 2015).

Health education is a discipline structure that provides an opportunity to learn about health through the interaction between educators and learners, using varied learning experiences. The learning process affects people to think. The learning process affects people to think about changing conditions or modifying attitudes to be healthier and more prosperous. Health promotions are aimed at helping people change their lifestyles to be healthier through varied efforts to raise awareness and create an environment that promotes positive health practices and lowers community health risks. (Swarjana, 2012)

Based on research by Ghebreyohans suggests that peer education is the best strategy to change youth behavior on a larger scale in a short period of time provided that it is well planned and appropriately implemented (Mohammed et al., 2017). The results of Purnomo, shows that the education method of peer increases the knowledge and attitude of control of HIV/AIDS students significantly compared to the lecture method. (Purnomo et al., 2013)

The results of the study by Faye ADAMEDKK on the knowledge and attitudes of Senegal sailors about HIV/AIDS (Knowledge and attitudes of a Senegalese sailors about HIV/AIDS), show that sailors have a low level of knowledge and a negative attitude toward people living with HIV. One of the government programs in the port in order to control and prevention of infectious diseases is the examination of VCT (voluntary counselling test) of HIV/AIDS in high-risk groups (children fruit vessel, Labor stevedoring, driver, Port community). In 2017 from 2639 
examination of the group of Risti (ABK, TKBM, DRIVER) as many as 9 ABK infected with HIV (Budiati, 2017).

Based on preliminary studies conducted at the port of Batu Ampar on October 1, 2019 on the fruit of the ship are all male genders of 20 children aboard 15 people said already having sexual intercourse with a boyfriend, or with other than the legitimate spouse mostly do not use condoms when related after being asked further, the reason that the ship's children have more than one partner and buy sex, almost all say the Salama's saturation factor works a monotonous and lack of interactions that require entertainment to release saturation. After being asked further than 15 people know the transmission of HIV/AIDS through sexual intercourse but not knowing the transmission of HIV through blood and from mother to her baby. This shows the fruit vessel is not aware of the information about HIV/AIDS in the HIV related AIDS is a virus, the way of transmission of HIV/AIDS and HIV/AIDS test. Most of the ship's children still have a negative attitude about HIV/AIDS saying people infected with HIV/AIDS are not allowed to work and should be avoid.

Based on the background of the problem, the authors feel interested to do research under the title of peer education influence on changes in knowledge and attitude in the prevention of HIV/AIDS on fruit vessel in Batu Ampar port area.

\section{B. METHODS}

This research is a quantitative study with the draft research quasi experiment without control group design with the approach of one group pre-test and post-test design by providing treatment to the subject of research then the result of the treatment is measured and analysed (Nursalam, 2017). The population in this study was the vessel in Batu Ampar port area amounting to 40 people. Samples of this study amounted to 36 respondents.

\section{RESULT AND DISCUSSION}

Table 1. Frequency distribution of the fruit vessel knowledge level before being given Peer Education on HIV/AIDS in Batu Ampar Port 2019

\begin{tabular}{|l|c|c|}
\hline \multicolumn{1}{|c|}{ Variabel Knowledge } & f & \% \\
\hline Good & 2 & 10 \\
\hline Enough & 4 & 20 \\
\hline Less & 14 & 70 \\
\hline Total & $\mathbf{2 0}$ & $\mathbf{1 0 0}$ \\
\hline
\end{tabular}

Table 2. Frequency distribution of fruit vessel attitude before being given Peer Education on HIV/AIDS in Batu Ampar Port 2019

\begin{tabular}{|l|c|c|}
\hline \multicolumn{1}{|c|}{ Variabel Atitude } & f & \% \\
\hline Positive & 8 & 40 \\
\hline Negative & 12 & 60 \\
\hline Total & $\mathbf{2 0}$ & $\mathbf{1 0 0}$ \\
\hline
\end{tabular}

Table 3. Frequency distribution of the ship's child knowledge after being given Peer Education on HIV/AIDS in Batu Ampar Harbor Year 2019

\begin{tabular}{|l|c|c|}
\hline \multicolumn{1}{|c|}{ Variabel Knowledge } & f & $\mathbf{\%}$ \\
\hline Good & 17 & 85 \\
\hline Enough & 3 & 15 \\
\hline Less & 0 & 0 \\
\hline Total & $\mathbf{2 0}$ & $\mathbf{1 0 0}$ \\
\hline
\end{tabular}


Table 4. Frequency distribution of fruit vessel attitude after being given Peer Education on HIV/AIDS in Batu Ampar Port 2019

\begin{tabular}{|l|c|c|}
\hline \multicolumn{1}{|c|}{ Variabel Atitude } & f & \% \\
\hline Positive & 20 & 100 \\
\hline Negative & 0 & 0 \\
\hline Total & $\mathbf{2 0}$ & $\mathbf{1 0 0}$ \\
\hline
\end{tabular}

Table 5. Frequency distribution of Peer Education influences on the change of knowledge of the ship's children on HIV/AIDS at Batu Ampar Port in 2019

\begin{tabular}{|l|c|c|c|}
\hline \multicolumn{1}{|c|}{ Variabel } & n & Mean & $\boldsymbol{p}$-Value \\
\hline Before Knowledge & 20 & 50,40 & 0,000 \\
\cline { 1 - 3 } After Knowledge & 20 & 84,80 & \\
\hline
\end{tabular}

Based on table 5 above, it can be known that the average knowledge before given peer Educationis 50.40, then increased to 84.80 after being given peer education. Based on the test Paired Sample T testget A P-value value of 0.000 . The significance value (2-tailed) $<0.05$ indicates there is a significant difference between the initial variable and the final variable. This indicates that there is a meaningful influence of Peer Education on the change of knowledge of the fruit vessel on HIV/AIDS in Batu Ampar port

Table 6. Frequency distribution of Peer Education influences on changes in the ship's children's attitudes about HIV/AIDS in Batu Ampar port in 2019

\begin{tabular}{|l|c|c|c|}
\hline \multicolumn{1}{|c|}{ Variabel } & n & Mean & $\boldsymbol{p}$-Value \\
\cline { 1 - 3 } Before Atitude & 20 & 25,40 & 0,000 \\
\cline { 1 - 3 } After Atitude & 20 & 35,65 & \\
\hline
\end{tabular}

That the average attitude of the fruit vessel before given peer Educationis 25.40, then increased to 35.65 after being given peer education. Based on ujiPaired Sample T testacquired Pvalue value of 0.000 . Significance value $(2$-tailed $)<0.05$ indicates there is a significant difference between the initial variable and the final variable. This indicates that there is a meaningful influence of Peer Education on the change in the attitude of the children of the ship on HIV/AIDS in Batu Ampar port.

The influence of Peer Education on the change of knowledge of children of the ship about HIV/AIDS in Batu Ampar port in 2019Based on the research results that the average knowledge before given peer education is 50.40 , then increased to 84.80 after being given peer education. Based on the test Paired Sample T Test could be a P-value of 0.000 . The significance value (2tailed) $<0.05$ indicates there is a significant difference between the initial variable and the final variable. This indicates there is a meaningful influence over the difference in the treatment given to each variable.

This research in line with the research of Gita Dewita (Dewita, Barus, Yusuf, \& Tjiptaningrum, 2016) concluded that the health education of peers effectively increase the knowledge of students at the nursing Academy 17 Karang Anyar about the prevention of HIV/AIDS, and the education of peers effectively increase the attitude of students in the nursing Academy 17 Karang Anyar about HIV/AIDS prevention the level of knowledge of children of the ship about HIV/AIDS before peer education is mostly in the category of less, as many as 14 respondents (70\%) have less knowledge because they have not been getting his specialty health education 
about HIV/AIDS so that when given some questions related to HIV/AIDS the majority of their answers are wrong, this is because theoretically they have not understood about HIV/AIDS. It was given a health education by peer educator knowledge children of the ship most of the respondents had a good knowledge category of 17 respondents (85\%).

A method of health education is a way or strategy used to make the message or health information provided can be easily understood by the target. In nursing community health education targets are individuals, families, groups and communities (Notoatmojo, 2010). The Peer group is the second social institution after the family that has a very important role for teenage life. In a peer group there is a social learning process, i.e. individuals adopt habits, attitudes, ideas, beliefs, values, and behavioural patterns in society, as well as develop them into the unity of the system within him. In addition, they also freely express their attitudes, judgments, and criticism and learn to deepen their personal relationships (Gita Dewita, Awal Bachtera Barus, Ali Imron Yusuf, 2016). In accordance with the research conducted by Ghebreyohans (Mohammed et al., 2017) suggests that peer education is the best strategy to change youth behavior on a larger scale in a short period of time provided that it is well planned and appropriately implemented.

From several theories and research analysis that have been explained above and from the results of research that has been done, researchers can conclude that the method of Peer Education is effective in improving the knowledge of the fruit vessel about HIV/AIDS in Batu Ampar port in 2019. This is due to the use of peer education method with the method of peer approach is a way or a proper and effective learning effort that is in accordance with the condition of the participants learn. The process of learning is done in a simple situation and learning conditions and the process of delivering the message or material HIV/AIDS is done freely and openly using the language and their own way of health education method is a way or strategy used for the message or health information provided can easily understand the target.

The influence of Peer Education on the change in the attitude of the fruit vessel on HIV/AIDS in Batu Ampar port in 2019 based on the results of the study that the average attitude of the fruit vessel before given peer education is 25.40 , then increased to 35.65 after being given peer education. Based on the test Paired Sample T Test obtained a P-value value of 0.000. Significance value $(2$-tailed $)<0.05$ indicates there is a significant difference between the initial variables and the final variables. This shows an influence that means a differentiated peer education against attitude change.

The results of this research are in line with the results of research conducted by Purwanti on the influence of Peer Education on the attitude in addressing HIV/AIDS that shows that the Peer Education (education) method is more effective to change attitudes. Post-test measurement results on the attitude of the fruit vessel in the prevention of HIV/AIDS diperolehseluruh20 respondents $(100 \%)$ Have a positive attitude of the measurement of the pre-test stance of most 12 respondents $(60 \%)$ Have a negative attitude which means that there are differences in the attitude of the fruit vessel in HIV/AIDS prevention. Thus there is a change in the positive attitude of the fruit vessel after being given treatment with peer education method. (Ningsih, 2017)

The results of this research show that the influence of peers (social groups) in the process of providing information relating to HIV/AIDS certainly affects the belief and emotion or feelings in responding to the problem of HIV/AIDS occurring in real life teenagers. The results of measuring the attitude in the prevention of HIV/AIDS in the vessel's children showed that the use of peer education methods affect the increase in the attitude of the fruit vessel. Good knowledge and supported by the beliefs and emotions or feelings of the fruit vessel related to the prevention of 
HIV/AIDS certainly affects the positive attitude of the fruit vessel in response and see the Solan of HIV/AIDS. It is in accordance with the opinion of all port in Notoatmodjo which says that a person's attitude is determined by knowledge, belief, and emotion as a whole intact (total atititude). A person's attitude toward an object is a supportive or favorable feeling as well as a feeling of not supporting or impartiality (unfavorable) on certain objects that individual social interactions react to form a particular pattern of attitude toward the various objects faced by them, such as factors affecting attitudes, personal experience, culture, others considered important, time media, educational institutions, and emotions within the individual. (Notoatmojo, 2010)

The implementation of peer education on the vessel in Batu Ampar Port is a method of learning by making peers as an educator or facilitator in spreading and conveying information to their own friends. The ability and background of an educator affects the attitudes of participants in responding to the material or message being delivered. Attitude differences are influenced by the ability to interact with the environment. Attitude is said to be a response that only arises when the individual is faced with a stimulus.

Education with peer-to-peer approach is a proper and effective way to learn and work in accordance with the conditions of the participants. The process of learning is done in a simple situation and learning conditions and the process of delivering a message or material of HIV/AIDS is done freely and openly using language and their own way. This indicates that the change in attitude in the vessel is influenced by the results of individual interactions with the environment obtained by respondents through a learning process in peer education. The interaction resulted in respondents ' reaction to the stimulus that came from outside and involved the knowledge and beliefs that the respondents had previously had relating to HIV/AIDS.

The results of Purnomo et al. shows that the education method of peer increases the knowledge and attitude of control of HIV/AIDS students significantly compared to the lecture method. A peer educator also has a better relationship with his peers. Good personal relationships are a major capital to influence and form a good attitude towards HIV/AIDS. So in the selection of peer educators, strive for those who have influence and become role models of his peers. (Purnomo et al., 2013)

From several theories and research analysis that have been explained above and from the results of research that has been done, researchers can conclude that the method of Peer Education can provide a positive attitude change in the vessel about HIV/AIDS in Batu Ampar port in 2019. This occurs because in the process of providing information relating to HIV/AIDS certainly affects the belief and emotion or feelings in responding to the problem of HIV/AIDS that occur in real life teenagers. The results of measuring the attitude in the prevention of HIV/AIDS in the vessel's children showed that the use of peer education methods affect the increase in the attitude of the fruit vessel. Good knowledge and supported by the beliefs and emotions or feelings of the fruit vessel related to the prevention of HIV/AIDS certainly affects the positive attitude of the fruit vessel in response and see the Solan of HIV/AIDS.

\section{CONCLUSION AND SUGGESTIONS}

Based on the research conducted by researchers with the title of peer education influence on changes of knowledge and attitude to the fruit vessel in BatuAmpar port in 2019. Conclusion that there is an influence on the knowledge of the fruit vessel before and after given peer 
education about HIV/AIDS in BatuAmpar port with value with the value of P-value 0.000 based on test Paired Sample T Test and there is an influence on the attitude of the fruit vessel before and after given peer education about HIV/AIDS in BatuAmpar port with value of $p$-value.

\section{ACKNOWLEDGEMENT}

Thank you to the respondents and puskesmas who have given the opportunity to be a research place as one of the supporting facilities. Thank to STIKes Awal Bros Batam who has been supporting the progress of this research so it can be a source to the fore in advancing science in the field of health.

\section{REFERENCES}

Budiati, R. E. (2017). Risiko Infeksi Menular Seksual Pada Anak Buah Kapal Di Pelabuhan Juwana Pati. JKM (Jurnal Kesehatan Masyarakat) Cendekia Utama, 5(1). https://doi.org/10.31596/jkm.v5i1.180

Dewita, G., Barus, A. B., Yusuf, A. I., \& Tjiptaningrum, A. (2016). Pendekatan Diagnostik dan Penatalaksanaan Pada Pasien HIV-AIDS Secara Umum. J Medula Unila.

Dinas Kesehatan Provinsi Riau. (2015). Profil Kesehatan Provinsi Riau 2015. Profil Kesehatan Riau 2015, 73-74.

Retrieved

from https://www.depkes.go.id/resources/download/profil/PROFIL_KES_PROVINSI_2015/04_Riau_201 5.pdf

Gita Dewita, Awal Bachtera Barus, Ali Imron Yusuf, A. T. (2016). Pendekatan Diagnostik dan Penatalaksanaan Pada Pasien Diagnostic and Treatment Approaches in Patients with HIV-. J Medula Unila, 6(1), 56-61.

Hadati, R. S., Linda, \& Masudin. (2015). Pengaruh Penyuluhan Kesehatan Terhadap Pengetahuan Siswa Tentang HIV/AIDS Di Madrasah Tsanawiyah Negeri Taipa Tahun 2015. Jurnal Ilmu Kesehatan, 1(19).

Ministry of Health Republic Indonesia. (2018). Hari AIDS Sedunia, Momen STOP Penularan HIV : Saya Berani, Saya Sehat! Kementerian Kesehatan, 433, 2018-2020. Retrieved from http://www.depkes.go.id/article/view/18120300001/hari-aids-sedunia-momen-stop-penularanhiv-saya-berani-saya-sehat-html

Mohammed, I., Ghebreyohans, G., Pasha, I., Humed, A., Hamed, A., Mohammedjimie, H., ... Ternikar, S. G. (2017). Abortion and the Load Of Its Immediate Complications In Orrota Maternity Hospital. IOSR Journal of Dental and Medical Sciences (IOSR-JDMS) E-ISSN, 16(10), 01-04. https://doi.org/10.9790/0853-1610140104

Ningsih, I. P. (2017). Pengaruh Program Pengelolaan Penyakit Kronis (PROLANIS) terhadap penurunan tekanan darah pada pasien hipertensi berbasis teori caring. Retrieved from http://repo.stikesicmejbg.ac.id/1793/

Notoatmojo, S. (2010). Konsep perilaku kesehatan. Promosi Kesehatan, Teori Dan Aplikasi, 43-64.

Nursalam. (2017). Metodologi Penelitian Ilmu Keperawatan. In Salemba Medika.

Purnomo, K. I., Murti, B., Suriyasa, P., Program, 1, Magister, S., Keluarga, K., \& Uns, P. (2013). Perbandingan Pengaruh Metode Pendidikan Sebaya Dan Metode Ceramah Terhadap Pengetahuan Dan Sikap Pengendalian Hiv/Aids Pada Mahasiswa Fakultas Olahraga Dan Kesehatan Universitas Pendidikan Ganesha. Jurnal Magister Kedokteran Keluarga, 1(1), 49-56. Retrieved from http://jurnal.pasca.uns.ac.id

Swarjana, I. K. (2012). Metodologi Penelitian Kesehatan - , MPH - Google Buku.

Tanto, C., Liwang, F., Hanifan, S., \& Pradipta, E. A. (2014). Kapita Selekta Kedokteran Edisi IV. In Jakarta : Media Aesculapius. https://doi.org/10.22146/buletinpsikologi.25163

UNAIDS 2017. (2017). 18.6 million girls and women living with HIV | UNAIDS. Retrieved from Joint United Nations Programme for HIV/AIDS website: http://www.unaids.org/en/resources/infographics/girls-and-women-living-with-HIV 